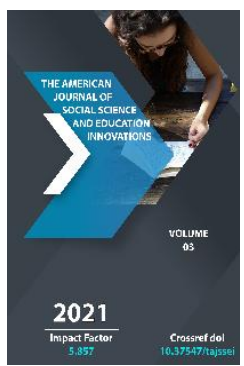

\title{
Turkish Students Which Studied In Germany And Foundations Supported Them
}

Diloromkhon Mirzaeva

Student, Fergana State University, Uzbekistan, Fergana City, Uzbekistan

Journal Website:

http://usajournalshub.c om/index,php/tajssei

Copyright: Original content from this work may be used under the terms of the creative commons attributes 4.0 licence.

\section{ABSTRACT}

The sending of about seventy talented young Turkestans to study in Germany in the 1920s was a major event in the socio-cultural life of those years. This article deals with the life of Turkestan students who studied in Germany at that time and those who did not, and the activities of foundations and organizations that helped them get an education.

\section{KEYWORDS}

Turkestan, Germany, students, “Komak” foundation, Turor Risqulov, Mustafa Chokayev, Prometheus, "Young Turkistan" magazine.

\section{INTRODUCTION}

After the independence of our country, many developed countries of the world recognized our independence and began to open their embassies, consulates and representative offices in our country. Apart from the CIS, Uzbekistan has also opened embassies in Asia,
Europe and the Americas. In addition, the German Society for the Promotion of Scientific Relations, the Goethe Institute, the Adenauer Foundation and many other international organizations have opened in Tashkent. Many businessmen, economic and trade specialists 
from our country have come abroad, and foreign experts in this field have come to Uzbekistan to start cooperation and exchange of experience. What is the situation in the Soviet Union in the recent past, when the situation is still developing? Were so many students and specialists sent abroad at that time? If so, how did they go about their careers and return home after graduation? To answer these questions, it is extremely important to study the fate of our students who were sent to study in Germany during this period, as the students were mainly sent to Germany to study. However, the subsequent fate of many such students was tragic, because in the Soviet era it was impossible to know the historical truth about it, and to study it was not encouraged. It is important to study the history of Uzbekistan's economic, political, cultural and educational relations with the outside world in the context of the ideology of national independence of the Soviet era. In view of this, we consider the study and work of our young men and women who were sent from Turkestan to Germany in the 1920s, the hardships of the oppression period, their place and importance in the history of our foreign scientific and cultural relations. we set ourselves the goal of learning.

\section{METHODS}

A number of scientific researches have been carried out in this field, including in the first years of our independence Professor Turkhan Kovunch's "Turkistan scientists working in Turkish medicine", Vali Qayumkhan's "Destroyed Fates", B. Yarashevsky's "Bukhara's students in Germany. 1922-1925" were published. In 2006, Sherali Turdiyev's book "They studied in Germany" and in 2018, Bahrom Irzayev's book "Uzbek youth and foreign education" were published, which described the fate of students who studied in Germany and those who did not. Orkhon Kovunch's article is short, giving a brief account of how several students, such as Ibrahim Yorkin, Tohir Chigatay, Ahmadjon Ibrahimov, and Saidalikhoja, were sent to Germany and stayed in Turkey. Articles by Vali Kayumkhan and B. Yarashevsky detail the history of sending students to Germany and the Soviet government's political repression.

During this period, various societies were established in Turkestan to send students to study abroad, including through charities such as "Ma'rifat" in Bukhara and "Komak" in Tashkent to attract talented young people to St. Petersburg, Saratov, Kazan, Ufa and Orenburg, Russia. along with the high schools and madrasas in their cities, they were sent to study at dorilfuns in foreign cities such as Istanbul, Berlin, and Cairo. Later, such students became writers and scholars such as Fitrat, Gozi Olim Yunusov, Khalid Said, Eson efendi Musayev, and lawyers such as Mustafa Chokayev, Ubaydulla Khojayev, and Norbotabekov. First of all, they considered it necessary to study the achievements and experiences of Germany, the most developed country in Western Europe at that time. To do this, first of all, it was possible to send local youth to Germany, as well as other advanced countries in the East and West, to get acquainted with the scientific and technological achievements and experiences of these countries, thereby saving the country from economic and cultural backwardness. In order to carry out this extremely important and complex project, it was necessary, firstly, to raise funds, secondly, to select talented young men and women, and thirdly, to obtain permission from their parents. In Turkestan, the government has begun sending students 
abroad, with the help of the Aid Association or through private channels. Beginning in the 1920s, many young people from Turkestan and Bukhara were selected and sent to study in Germany.

In late 1923, the chairman of the Council of People's Commissars of the Turkestan ASSR, Turor Rizkulov, visited Germany, where he returned to learn about the real situation of Bukhara and Turkestan students. He points to the inappropriateness of various suspicions and suspicions of some Russian Bolshevik leaders in Turkestan and the local mangroves under their influence, and other issues:

"There are 11 students in Turkestan and 47 in Bukhara. 7 Turkestans are Uzbeks and 4 are Kazakhs. Turkestan students understand their responsibilities well, and then there is an effort to return to their homeland and benefit their people's government. There are 35 Uzbeks, 8 Tatars ( 4 of them are girls), 5 Turkmens and 1 Jew in Bukhara.

All students are housed in families to learn German faster...

Although they did not deal with Russian political refugees, they did meet with political refugees from the East (Turks, Tatars, etc.), but they did not affect our students"[1].

The archival documents of the Ministry of Foreign Affairs of the Federal Republic of Germany of the 1920s show that even then there was a strong cultural exchange between the two countries. The Representative of the Republic of Bukhara for Culture (1923) submitted to the Ministry of Foreign Affairs a list of 17 pupils and students of Bukhara schools who were to live in German families and receive education in German. At the time, Ibrahim Behzod, a Turkish student, was responsible for teaching students in their own language. Among the students were Jadids who wanted to work at a school in Turkestan.

\section{RESULTS}

Students from Bukhara and Turkestan, who were sent to Germany in 1923, published their scientific and literary journals "Komak" and participated in the pages of the journal with scientific and journalistic articles and poems. Many of them returned to Uzbekistan after graduation and began working in their homeland under a totalitarian regime. Some of them did not return to Uzbekistan, but stayed in Germany. wrote articles in the press about the history, culture and life of the peoples of Central Asia during the colonial period. Not content with this, they planned to publish a special magazine that would fight for Turkestan's independence.

In December 1929, Mustafa Chokayev published the first issue of Yosh Turkiston in Uzbek in Paris with the help of Prometheus, an organization that supported the struggle for independence of the peoples of the Soviet colony in Poland. Former students Tahir Chigatay, Oktay, Ahmad Naim, who studied in Germany together with the editor Mustafa Chokayev and did not return to Uzbekistan, took an active part in the magazine with their articles and poems. -Political life, regularly published works exposing the colonial policy of the Soviets.

"According to the Central State Archives of Uzbekistan, students sent from Bukhara and Turkestan to study in Germany received regular scholarships, material and moral support through the Deputy Commissioner for Foreign Affairs of the RSFSR Chicherin and others. He was aware of their socio-economic status, needs, aspirations, ideological and political 
mood. In 1921, for example, 80 percent of the proceeds from national masterpieces and 20 percent from goat races went to students"[2, 12].

\section{DISCUSSION}

During this period, after graduating from Germany, students Sattor Jabbor, Tolagan Momin, Muhammad Khojayev, Sultan Matkul, Azimjon Berimjon, Rauf Rasuli, Khayrinisa Majidkhonova, Maryam Sultanmuradova, Gulsum Rahimova Rukiya Khojayeva returned to Uzbekistan. Nasriddin Sherahmedov and others used the advanced knowledge and experience gained in Germany and worked selflessly for the development of our republic. However, many of them were accused by the Soviets of being members of a nationalist organization and were brutally shot dead on October 4-9, 1938.

A group of our students, such as Tahir Chigatay, Ahmadjon Ibragimov, Afzal Abdusaid, Ibrahim Yorqin, Abduvahob Ishaq, Saida Sherahmad qizi, stayed in Germany due to the repressions in Turkestan. Later, when the Nazis came to power, they were forced to move to Istanbul and Ankara, Turkey, where they worked as doctors, professors and teachers at universities.

We believe that working in the archives of our country, as well as in countries such as Turkey, France, England and Japan, and studying newspapers and magazines published in those years, we can find new information about our students who stayed abroad for various reasons. In addition, the children of the aforementioned former students currently living in Turkey will no doubt help to further this research.

\section{CONCLUSION}

In short, all the students who studied in Germany, even those who did not return to their homeland, contributed to the independence of our people, opened many new schools to help the youth of our nation to get an education and enjoy the rays of light. organized, took an active part in the political process. In addition, the organizations and societies that sent them to study in foreign countries, especially in Germany, have played an important role in the future of our country. The people of our nation have spared no effort to educate the youth and serve them in the cause of freedom, and have worked together under the leadership of the Enlightenment to play a significant role in raising the consciousness and worldview of the people of our nation.

\section{REFERENCES}

1. Risqulov Turor. Our students in Germany. "Turkiston" newspaper, 1923. December 19.

2. Turdiyev Sh. They studied in Germany. Tashkent, "Akadem - Xizmat", 2006. p.12

3. Shamsuddinov R., Muminov X. History of Uzbekistan. Educational-methodical material. Andijan, 2011.

4. Irzaev B. Uzbek youth and foreign education. Tashkent, “Akademnashr", 2018. p.208.

5. Murtazaeva R. History of Uzbekistan. Textbook. Tashkent, 2003.

6. Abdurakhmonova, M. M., ugli Mirzayev, $M$. A., Karimov, U. U., \& Karimova, G. Y. (2021). Information Culture And Ethical Education In The Globalization Century. The American Journal of Social Science and Education Innovations, 3(03), 384-388. 
The American Journal of Social Science and Education Innovations (ISSN - 2689-100x)

7. Karimov, U., \& Abdurakhmon, A. (2017). INNOVATIVE INFORMATION TECHNOLOGY IN EDUCATION. Форум молодых ученых, (5), 9-12.

8. Karimov, U., \& Kasimov, I. (2018). THE IMPORTANCE OF MODERN INFORMATION TECHNOLOGIES IN DEVELOPMENT OF DISTANCE EDUCATION. In Перспективные информационные технологии (ПИТ 2018) (pp. 1186-1187).

9. Karimov, U., Kaxarov, S., Yokubjonov, S., \& Ziyodov, D. (2018). USING NEW INFORMATION TECHNOLOGIES IN DISTANCE LEARNING SYSTEM. In HOBAЯ ПРОМЫШЛЕННАЯ РЕВОЛЮЦИЯ В ЗЕРКАЛЕ СОВРЕМЕННОЙ НАУКИ (рp. 911).

10. Otamuratov S., Khusanov S., Ramatov Yu. Basics of spirituality. Toolkit. Tashkent, 2002.

11. Ziyomukhammadov B. Pedagogy. Toolkit. Tashkent, 2006, p. 37.

12. Каримов, У., Хакимова, Д., \& Халилов, Л. (2018). ИНФОРМАЦИОННОЕ И КОММУНИКАЦИОННОЕ ТЕХНОЛОГИИ ВЛИЯНИЕ НА ОБРАЗОВАНИЕ В ТЕХНИЧЕСКОМ ОБСЛУЖИВАНИЕ. Мировая наука, (10), 193-197.

13. Usmonov K. Integration of Uzbekistan into the community. Tashkent, 2003.

14. Каримов, У., \& Каримова, Г. (2018). ГЕОПОЛИТИЧЕСКАЯ КОНКУРЕНЦИЯ В ИНФОРМАЦИОННОМ ПРОСТРАНСТВЕ. In Перспективные информационные технологии (ПИТ 2018) (рр. 1368-1372).

15. Odilqoriev $X$. Constitution and civil society. Tashkent, 2002.

16. Abdullaev M., Abdullaev A. History of spirituality and culture. Fergana, 1998.

17. Murtazaeva R. Tolerance as an integrating factor in multinational Uzbekistan. Tashkent, 2010.
18. Levitin L. Uzbekistan is at a turning point. Tashkent, 2001.

19. Yarashevsky B. Students of Bukhara in Germany 1922-1925. - T .: 1991.

20. Qayumkhan Vali, Destroyed parts. - T .: 1992.

21. Ottoman M., Support for students in Berlin. // Turkiston. December 18, 1922.

22. Shokir Suleyman, Turkestan students in Europe // Turkistan. January 1, 1923.

23. Каримова, Г. Й. (2018). РОЛЬ КОНСТИТУЦИИ В ПОСТРОЕНИИ ПРАВОВОГО ГОСУДАРСТВА И ГРАЖДАНСКОГО ОБЩЕСТВА. Теория и практика современной науки, (2), 161-163.

24. Normatova D. E. THE SOCIAL AND MORAL VIEWS OF MICHELLE ECKEM DE MONTEN //Scientific Bulletin of Namangan State University. - 2019. - T. 1. - №. 10. - C. 184187.

25. Eshov B.J. History of statehood of Uzbekistan. Study giude. Tashkent, 2009.

26. Normatova D. E. PECULIARITIES OF ANTHROPOCENTRISM AND HUMANISM OF THE SOCIO-PHILOSOPHICAL THOUGHT OF WESTERN EUROPE IN THE ERA OF RENAISSANCE //Scientific Bulletin of Namangan State University. - 2019. - T. 1. №. 5. - C. 168-173.

27. Normatova, D. E. (2021). The Development Of Socio-Philosophical Thought In Western Europe On The Eve Of The End Of The Renaissance. The American Journal of Social Science and Education Innovations, 3(03), 371-377.

28. Bobojonova D. Socio-economic relations in Uzbekistan. Study guide. Tashkent, 1999. 